Case report

\title{
ACUTE ABDOMEN AND LIVER ABSCESS CAUSED BY PENETRATING METALLIC FOREIGN BODY IN A MARE
}

\author{
GÓSS Geórgia Camargo ${ }^{1}$, DUARTE Claudia Acosta ${ }^{1 *}$, RODRIGUES Claudia \\ Medeiros $^{2}$, POZZOBON Ricardo ${ }^{2}$, TROST Maria Elisa ${ }^{1}$, BRANDOLT Inacio \\ Manassi da Conceição ${ }^{1}$
}

${ }^{1}$ Federal University of Pampa, Uruguaiana, Brazil; ${ }^{2}$ Federal University of Santa Maria, Uruguaiana, Brazil

(Received 12 March, Accepted 21 May 2019)

\begin{abstract}
The ingestion of sharp foreign bodies that cause penetrating wounds to the gut and surrounding structures and its consequences are not often seen in equine medicine. When animals ingest these objects, they tend to have colic episodes and peritonitis, as well as to be prone to abscess formation. The aim of the current case report is to describe liver abscesses and peritonitis, with abdominal adhesions, caused by a penetrating metallic foreign body that was swallowed by a Crioulo mare, which had been showing a history of recurrent colic episodes for 4 months. The animal was subjected to median celiotomy due to suspect enterolithiasis. During the procedure, abdominal adhesions, blood clots in the intestinal loops and enteroliths were observed. These severe changes led to the mare death while she was still recovering from anaesthesia. Necropsy findings revealed abscess formation in the liver, abdominal adhesions, diffuse peritonitis and a penetrating foreign body in the liver. The relevance of the present case study lies on the fact that the assessed mare presented a stable chronic condition, although she had peritonitis and abdominal abscesses. This observation reinforces the importance of assessing all abdominal organs in horses with recurrent colic episodes. The evaluation of abdominal organs through complementary exams and necropsy can help identifying foreign objects inside these animals and it contributes to the challenging diagnosis of colic syndrome.
\end{abstract}

Key words: peritonitis, colic, diagnosis, equine.

\section{INTRODUCTION}

Reports about the ingestion of penetrating foreign bodies (FB), and about its consequences on animals' health condition, are often found in medical literature on ruminants; however, they are scarce in the overall literature on equine medicine [1]. Episodes of foreign body ingestion can be attributed to horses' eating habits, since they tend to be selective [2]. This syndrome is acknowledged as multifactorial [3].

\footnotetext{
*Corresponding author: e-mail: caduarte74@gmail.com
} 
Thus, the ingestion of penetrating foreign bodies by horses causes abdominal pain due to the following factors: adhesion formation in bowel segments [4], peritonitis [1] and intra-abdominal abscesses [5].

The aim of the current study was to describe liver abscesses, peritonitis and abdominal adhesions that were caused by the ingestion of a penetrating metallic foreign body by a mare who had been presenting recurrent colic episodes.

\section{CASE PRESENTATION}

A 9-year-old Crioulo mare who had been presenting colic episodes was treated at the University Veterinary Hospital (HUVet) at Federal University of Pampa, Uruguaiana County - RS. According to the mare's owner, she already had two colic episodes 4 months before she was taken to HUVet; at that time, she was treated for leptospirosis and babesiosis. The colic episodes were featured by alternating moments of tranquillity and intense pain, which made the mare agitated - she rolled her body on the floor every time she was in pain. The mare had diarrhoea in the second colic episode, after she was medicated. A hemogram was performed after this diarrhoea episode. She was treated with fluid therapy to stop the diarrhoea and presented clinical improvement after it. The owner did not have the haematological values recorded in this hemogram and did not know the drugs and fluid type administered to the animal at that time. However, according to him, she presented hyporexia and progressive weight loss from the first colic episode to the day she was treated at HUVet. The mare was not fed with concentrates, but only on alfalfa hay and green grass.

The mare was taken to HUVet during the third episode of abdominal pain. The pain symptoms started approximately 6 hours before she arrived at the hospital. The mare was responsive during clinical evaluation, which showed emaciation and signs of abdominal discomfort. The overall physical examination revealed moderate dehydration, pale oral mucosa and a dark ring around the teeth - which suggested toxaemia, 3-second capillary filling time, as well as heart rate of $60 \mathrm{bpm}$ and respiration rate of 24 respirations per minute. Evaluation of the digestive system showed intestinal hypomotility in four auscultation quadrants and lack of defecation. There was no reflux during nasogastric probing and no peritoneal fluid was found during paracentesis. Transrectal palpation showed a painful reaction to cecum examination, as well as scarce and dry faeces in the rectal ampulla. Laboratory tests revealed thrombocytosis $(411,000$ cells $/ \mu \mathrm{L})$, leucocytosis $(17,200$ cells $/ \mu \mathrm{L})$ due to neutrophilia (12,900 cells / $\mu \mathrm{L})$, hyperproteinaemia $(1.08 \mathrm{~g} / \mathrm{L})$ and high serum aspartate aminotransferase levels $(610 \mathrm{U} / \mathrm{L})$.

The mare's medical history and clinical frame led to the diagnostic suspicion of enterolithiasis. She was subjected to median celiotomy; thus, she received fluid therapy with $0.9 \%$ sodium chloride $(1 \mathrm{ml} / \mathrm{kg} / \mathrm{h})$, flunixin meglumine $(1.1 \mathrm{mg} / \mathrm{kg}, \mathrm{SID})$, and meloxicam $(0.6 \mathrm{mg} / \mathrm{kg}$, SID), both anti-inflammatory drugs were used at different 
times prior to the surgical procedure. Lidocaine $(1.5 \mathrm{mg} / \mathrm{kg})$ was intravenously (IV) administered (bolus) via peripheral catheter in the jugular vein; moreover, mineral oil (5 ml/kg, QID) was orally administered.

The anaesthetic protocol comprised xylazine $(2 \mathrm{mg} / \mathrm{kg}) \mathrm{IV}$, delivered as preanaesthetic medication, ketamine $(2 \mathrm{mg} / \mathrm{kg})$ and midazolam $(0.1 \mathrm{mg} / \mathrm{kg}) \mathrm{IV}$ delivered for anaesthesia induction purposes. Anaesthesia maintenance was based on isoflurane. Besides the anaesthetic agents, prophylactic antibiotic therapy with ampicillin $(4 \mathrm{mg} /$ $\mathrm{kg}$ ) combined with gentamicin $(6 \mathrm{mg} / \mathrm{kg})$, continuous lidocaine (0.05 $\mu \mathrm{g} / \mathrm{kg} / \mathrm{min})$, dimethyl sulfoxide $(1 \mathrm{~g} / \mathrm{kg})$ and dopamine $(140 \mu \mathrm{g} / \mathrm{kg} / \mathrm{min})$ infusion was adopted during surgery. Surgery lasted approximately 3 hours and the animal remained stable throughout the procedure.

The abdominal cavity was accessed through an incision from the mare's skin to her subcutaneous tissue, linea alba and peritoneum. Abdominal evaluation showed the cecum apex to be adhered to the parietal peritoneum in the xiphoid region, as well as a large blood clot in the serous membrane of the cecum and another one in the large bowel. There was considerable amount of fibrin and diffuse adherence throughout the abdominal cavity. The left dorsal colon presented 2 enteroliths (diameter $=15$ and $8 \mathrm{~cm}$ ), which were removed through the pelvic flexure enterotomy after the bowel segment was washed (Figure 1). The surgical procedure showed unfavourable prognosis and, although the owner did not resort to euthanasia, the mare died while she was still recovering from anaesthesia.

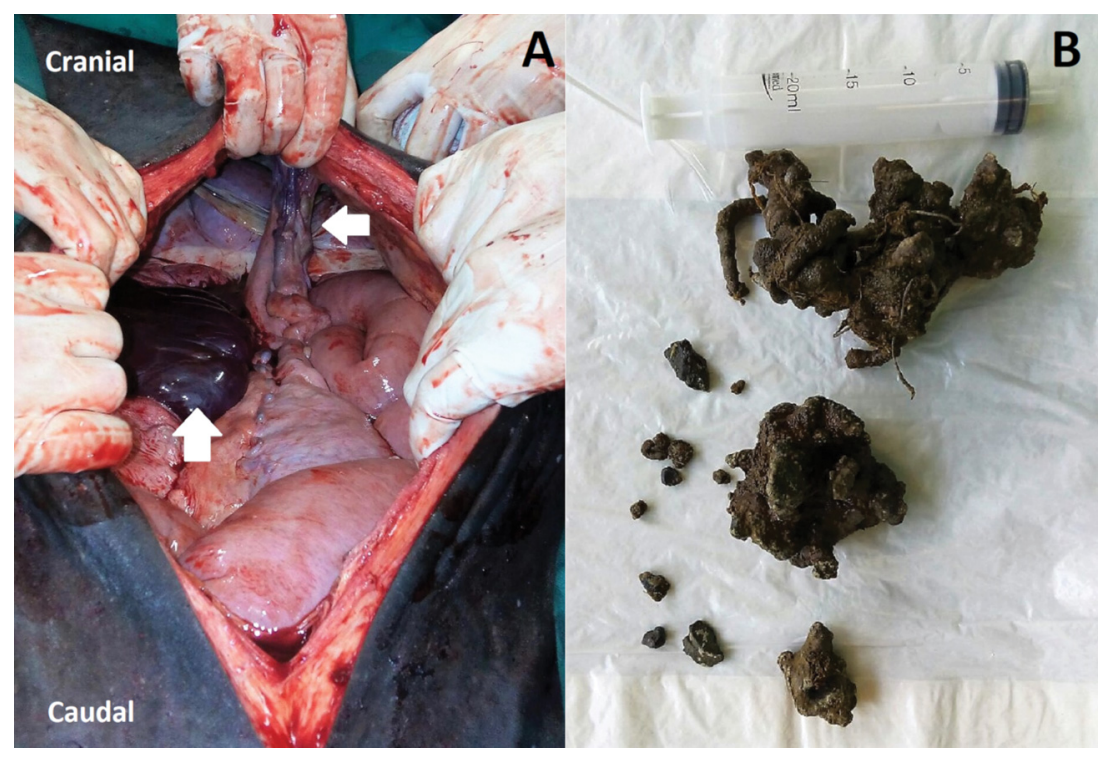

Figure 1. A) Inspection of the abdominal cavity during surgery. The cecum apex was adhered to the abdominal wall (horizontal white arrow) and there was a large blood clot in the left ventral colon (vertical white arrow). B) Enteroliths were removed through pelvic flexure enterotomy. The two biggest ones measured approximately 15 and $8 \mathrm{~cm}$ (in diameter). 
Necropsy results showed portal vein thrombosis and multifocal hepatic abscess associated with the presence of a hepatic foreign body found inside an elongated abscess with a fibrous capsule $(18 \times 5 \mathrm{~cm})$, identified as a wire fragment (15-cm long) (Figure 2). The abdominal cavity presented pronounced and diffuse fibrinous peritonitis with multifocal adhesions of intestinal loops and focally-pronounced mural thrombosis in the colon. However, it was not possible to determine the path taken by the foreign body.

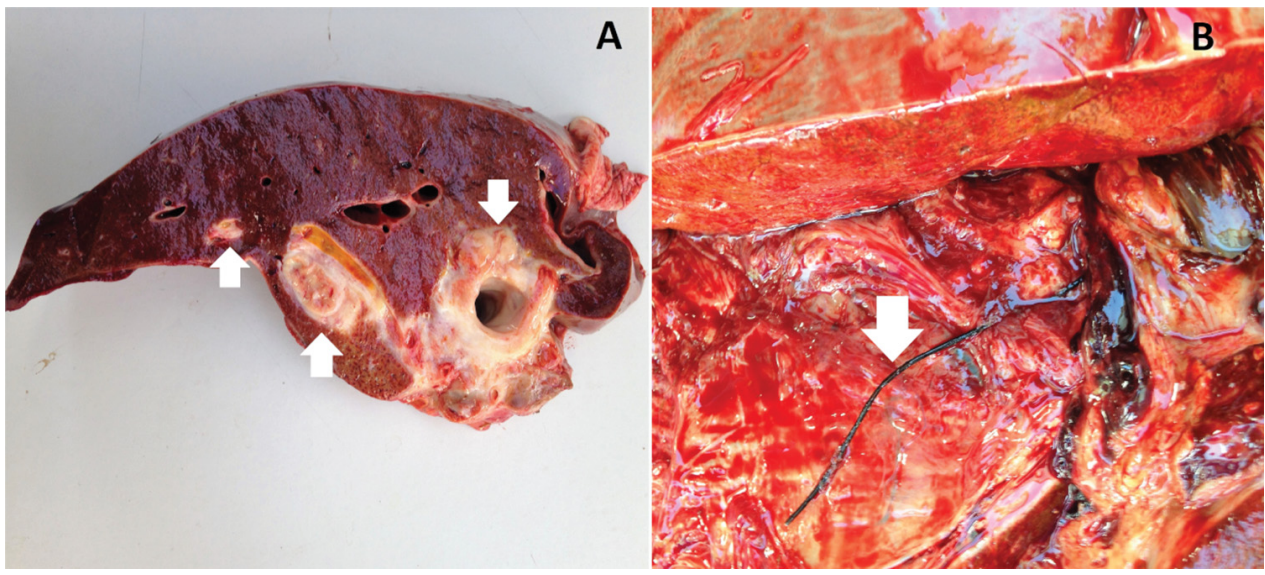

Figure 2. Necropsy pictures. A) Liver abscesses. B) Penetrating foreign body (wire) in the liver (white arrow).

\section{DISCUSSION}

The current case report addresses three simultaneous conditions and enterolithiasis. This finding made the herein reported case different from other reports on abdominal adhesion, peritonitis and liver abscesses secondary to the ingestion of a penetrating foreign body $[1,4,6,7]$. According to previous reports on peritonitis secondary to FB ingestion, the affected animals often present acute and severe conditions $[1,7]$. Results in these reports are not consistent with the present case, since the herein assessed mare showed a chronic condition of recurrent colic episodes.

The incidence of several painful episodes associated with the mare's age and alfalfa hay intake has led to previous enterolithiasis diagnosis, since her symptoms were similar to previous observations about Crioulo horses with enterolithiasis history, to their feeding habits and age [8]. However, although two enteroliths were removed from the animal, other severe changes had happened in her gastrointestinal tract and this finding reinforced the hypothesis that colic syndrome cases may be multifactorial [3].

The incidence of penetrating foreign bodies in the abdominal cavity of horses has low casuistic [1]; however, when FBs are ingested by them, the prognosis is unfavourable, mainly if the objects perforate the animals' intestinal loops. As previously mentioned, horses are often subjected to euthanasia when it happens, given the clinical frame 
caused by this health condition and the financial issues faced by owners due to it $[1,4,7]$. The mare died soon after the end of the surgical procedure; this outcome corroborated the unfavourable prognosis.

Peritonitis secondary to the ingestion of penetrating FBs can be observed in case reports that address horses who presented colic episodes, as well as similar necropsy findings such as compromised intestinal loops, spleen and liver, as well as diffuse peritonitis [1,7]. The mare treated in the current study showed progressive chronic disease signs without splenic involvement; however, her liver and a large portion of her intestinal loops were compromised, besides, she presented peritonitis.

Colic episodes are also described as a clinical sign of intra-abdominal abscesses. Based on studies about this topic, on average, 41 out of 61 animals presenting this condition have colic episodes, concurrent to other clinical signs such as anorexia, depression, weight loss and tachycardia [5]. The herein evaluated mare presented several colic episodes with tachycardia, as well as hyporexia and, consequently, weight loss. Although, based on the owner's reports, she was not depressed during the course of the disease, her symptoms matched the ones described in the literature.

Abdominal abscesses may be secondary to orchiectomy, foaling, abdominal surgery and to wounds caused by the penetration of foreign bodies in the abdominal region [5]. On the other hand, liver abscesses can be associated with portal vein thrombophlebitis, abdominal surgeries and with the ingestion of foreign objects capable of perforating the intestinal loops [6]. With respect to the mare in the present report, the initial suspicion did not include abscesses caused by FB ingestion, given the mare's history of absence of abdominal wounds, foaling or previous surgeries, as well as to her feeding habits. However, necropsy has indicated that the wire found within the abscess was the primary cause of her health condition.

Abdominal abscesses can be diagnosed through transrectal or transabdominal ultrasound examinations [6]; however, when it comes to liver abscesses, the examination is restricted to the transabdominal access [7]. It was not possible to have an ultrasound in the present case; however, the clinical suspicion of liver abscess must be checked through blood count and leukogram, which should be carried out carefully, since leucocytosis and increased activity liver enzymes are not always common [7]. This outcome was observed in the herein assessed animal, whose diagnosis was more consistent with peritonitis and with values reported in the literature [1].

\section{CONCLUSION}

Although uncommon, the ingestion of foreign bodies by horses has severe consequences on their health condition. Thus, this possibility should be taken into consideration when it comes to analysing different causes of colic episodes at the time of making possible differential diagnoses. The current case report reinforces the idea that clinical assessments in animals with acute abdominal pain should not be restricted 
to their gastrointestinal tract; actually, all organs in the abdominal cavity should be assessed. In addition, the reported case also highlighted the importance of performing complementary exams and necropsy.

\section{Authors' contributions}

GCG wrote the article and performed the treatmentof the animal; CAD, RP, CMR e IMCB reviewed the manuscript and performed thetreatment; MET reviewed the work and performed the necropsy.

\section{Declaration of conflicting interests}

The author(s) declared no potential conflicts of interest with respect to the research, authorship, and/or publication of this article.

\section{REFERENCES}

1. Lohmann KL, Lewis SR, Wobeser B, Allen AL: Penetrating metallic foreign bodies as a cause of peritonitis in 3 horses. Can Vet J 2010, 51(1):1400-1404.

2. Collery L: Observations of equine animals under farm and feral conditions. Equine Vet J 1974, 6(4):170-173.

3. Ferreira C, Palhares MS, Melo UP, Gheller VA, Braga CE: Cólicas por compactação em equinos: etiopatogenia, diagnóstico e tratamento. Acta Vet Bras 2009, 3(3):117-126.

4. Saulez MN, Burton A, Steyl JCA, Williams H, Clift SJ: Perforation of the gastrointestinal tracts of four horses by metallic wires. Vet Rec 2009, 164(1):86-89.

5. Arnold CE, Chaffin MK: Abdominal abscesses in adult horses: 61 cases (1993-2008). JAVMA 2012, 12(1):1659-1665.

6. Sellon D, Spauldin K, Breuhaus BA, Katz L, Mealey R: Hepatic abscess in three horses. JAVMA 2000, 216(6):882-887.

7. Ramirez S, Mirza M, Burba DJ, McClure RJ: Peritonitis secondary to ingested wood foreign bodies in 2 horses. Equine Vet Educ 1997, 9(3):133-135.

8. Santos AC, Curcio BR, Finger IS, Junior JC, Nogueira CEW: Enterolithiasis in Crioulo horses. Acta Scienc Vet 2017, 45(1):1-5. 


\title{
AKUTNI ABDOMINALNI APSCES USLOVLJEN PENETRACIJOM METALNOG STRANOG TELA KOD KOBILE
}

\author{
GÓSS Geórgia Camargo, DUARTE Claudia Acosta, RODRIGUES Claudia \\ Medeiros, POZZOBON Ricardo, TROST Maria Elisa, BRANDOLT Inacio Manassi \\ da Conceição
}

Ingestija stranog tela koje probije intestinalni trakt i uslovljava oštećenja okolnih tkiva sa posledicama, retko se sreće kod konja. U slučaju da se desi ingestija ovakvih stranih tela, obično se manifestuje simptomima kolika i peritonitisa, kao i formiranjem apscesa. Cilj ovog prikaza slučaja bio je da se opiše apsces jetre kao i peritonitis sa formiranjem adhezija u abdomenu, uslovljenih penetracijom metalnog stranog tela koje je progutala kobila rase Crioulo. Anamnestički podaci su se odnosili na postojanje rekurentih epizoda kolika u trajanju od 4 meseca. Kod životinje je, zbog sumnje na enterolitijazu, obavljena medijalna celiotomija. Tokom hirurške procedure, uočene su abdominalne adhezije kao i ugrušci krvi u zavojima creva. Kao posledica ovih teških promena, kobila je prilikom buđenja iz anestezije uginula. Prilikom obukcije, uočeni su apscesi u jetri, priraslice u abdomenu, difuzni peritonitis i strano telo koje je penetriralo tkivo jetre. Značaj analize ovog slučaja je u činjenici da je prva procena stanja kobile ukazivala na stabilno hronično stanje, iako su bili prisutni peritonitis i abdominalni apscesi. Ovaj nalaz ukazuje na značaj procene stanja svih organa abdomena kod konja kod kojih postoje rekurentne epizode kolika. Evaluacija stanja organa abdomena putem sveobuhvatnog ispitivanja i obdukcije, mogu da pomognu u identifikaciji stranih tela kod ovih životinja i da doprinesu relativno kompleksnoj dijagnostici količnog sindroma konja. 